\title{
The relation of tactile thresholds to histology in the fingers of elderly people
}

\author{
M F BRUCE \\ From the Department of Anatomy, Aberdeen University
}

SUMMARY Touch thresholds in a group of elderly people were determined for three sites on the little finger. They were found to be raised by some two and a half times in each site, in comparison with a group of young subjects. An age-associated reduction in the number of Meissner corpuscles also was observed, but it is suggested that this may reflect a general reduction in peripheral innervation and may not be necessarily directly related to the decrease in tactile sensitivity. No significant sex differences were found either in sensory thresholds, or in the population density of corpuscles.

The function of the Meissner corpuscle still is not certain. Bruce and Sinclair ${ }^{1}$ investigated the sensory thresholds to passive tactile stimulation on three sites on the little finger in comparison to the populations of Meissner corpuscles in the same three sites in amputated fingers. No satisfactory relationship was found.

Because the subjects used in that investigation were all young adults, and because it is known that Meissner corpuscles decrease in number and alter their morphology as age advances, ${ }^{2} 3$ Meissner counts and threshold values in a group of elderly people have been studied, using identical procedures to those of the earlier study.

\section{Materials and methods}

Histology Skin was taken from six male (mean age $70 \cdot 3$ years: range 63-75 years) and six female cadavers (mean age $73 \cdot 8$ years: range $62-83$ years). The sites sampled were the palmar, lateral (radial) and the dorsal areas of the little finger of the left hand. The skin was fixed in Bouin's fluid, embedded in paraffin wax, cut normal to the skin surface in serial sections at $15 \mu \mathrm{m}$, and then stained according to the double silver impregnation technique of Fitzgerald. ${ }^{4}$ Each section was scanned for the presence of organised endings, and then all the Meissner corpuscles in an area varying from six to nine $\mathrm{mm}^{2}$ were counted. The concentrations of corpuscles were then expressed as corpuscles $/ \mathrm{mm}^{2}$.

Sensory testing The apparatus, the procedure and

Address for reprint requests: Mrs MF Bruce, Department of Anatomy, Marischal College, Aberdeen, Scotland AB9 1 AS.

Accepted 11 April 1980 test sites were described previously, ${ }^{1}$ except that five of the volunteers were tested in their own homes; the remainder were tested in a quiet room within the department. All those who took part were healthy and active; all were right-handed, and none had previous experience of sensory testing. All the seven males and six of the eight females were doctors; the remaining two females were doctors' wives. The mean age of the males was $69 \cdot 7$ years, with a range of $62-79$, and the mean age of the females was 71.9 . with a range of 65-78.

\section{Results}

HISTOLOGY

General The distribution of the corpuscles was much more irregular than in the young material studied previously. Many were situated at some distance from the epidermis and others were orientated obliquely in their papillae (fig 1). There were no obvious morphological differences between the corpuscles from the palmar and the lateral surfaces; in both sites there was a predominance of large lobulated forms (fig 2). No age changes in morphology were evident in the corpuscles on the dorsum.

Effect of site The mean counts of Meissner corpuscles from the cadaver material are shown in table 1. The figures for the palmar and lateral sites did not differ significantly, but each was significantly greater than that for the dorsal site.

Effect of sex There were no significant differences between the sexes in the Meissner counts at any site (table 1).

Effect of age Table 2 compares the figures obtained from the elderly cadavers and those 


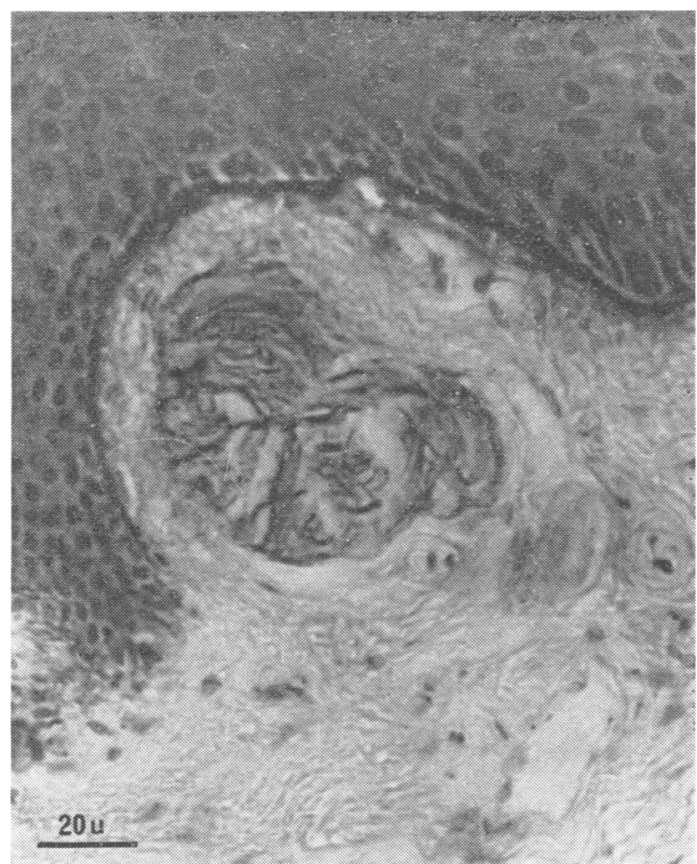

Fig 1 Obliquely orientated Meissner corpuscle; palmar surface, fifth finger, female subject aged 70 years.

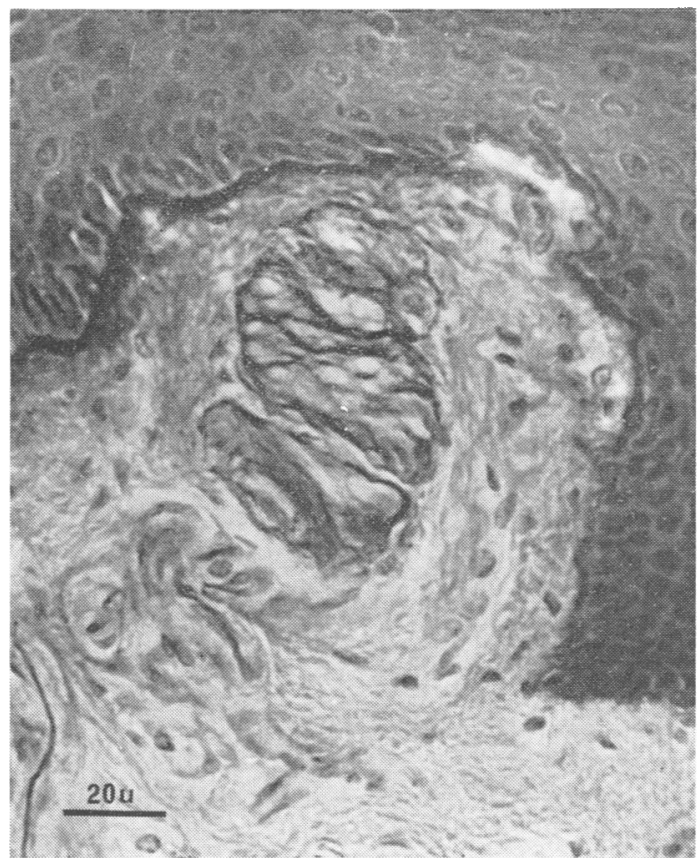

Fig 2 Large lobulated Meissner corpuscle; from the same siecimen as fig 1 .
Table 1 Mean number of Meissner corpuscles per $\mathrm{mm}^{2}$, with standard errors

\begin{tabular}{|c|c|c|c|}
\hline & \multicolumn{3}{|l|}{ Site } \\
\hline & Palmar & Lateral & Dorsal \\
\hline \multirow{3}{*}{ Males } & $5 \cdot 4$ & $5 \cdot 8$ & $0.9 *$ \\
\hline & $\stackrel{-}{=}$ & \pm & \pm \\
\hline & $1 \cdot 0$ & 1.6 & $1 \cdot 2$ \\
\hline \multirow{3}{*}{ Females } & $6 \cdot 1$ & $6 \cdot 3$ & $0.6+$ \\
\hline & \pm & \pm & \pm \\
\hline & $1 \cdot 2$ & $1 \cdot 0$ & $0 \cdot 2$ \\
\hline \multirow{3}{*}{ Combined } & $5 \cdot 7$ & 6.0 & $0 \cdot 7_{ \pm}^{+}$ \\
\hline & $\neq$ & \pm & $\therefore$ \\
\hline & $0 \cdot 8$ & 0.9 & $0 \cdot 2$ \\
\hline
\end{tabular}

*Significantly lower than the palmar $(p<0.01)$ or the lateral $(p<0.02)$ values.

†Significantly lower than the pal.nar $(p<0.01)$ or the lateral $(p<0.01)$ values.

ISignificantly lower than the palmar $(p<0.001)$ or the lateral $(\mathrm{p}<0.001)$ values.

Table 2 Mean number of corpuscles per $\mathrm{mm}^{2}$, with standard errors

\begin{tabular}{lccl}
\hline & Site & & \\
\cline { 2 - 4 } & Palmar & Lateral & Dorsal \\
\hline *Combined sexes & $20 \cdot 7$ & $17 \cdot 4$ & $3 \cdot 1$ \\
young group & - & \pm .5 & \pm \\
$\mathrm{n}=5$ & $2 \cdot 3$ & $1 \cdot 5$ & $1 \cdot 4$ \\
$\begin{array}{l}\text { Combined sexes } \\
\text { elderly group }\end{array}$ & $5 \cdot 7$ & $6 \cdot 0$ & $0 \cdot 7$ \\
$\mathrm{n}=12$ & \pm .8 & \pm .9 & $\pm \cdot 2$ \\
\hline
\end{tabular}

${ }^{*}$ From Bruce and Sinclair. ${ }^{1}$

obtained from young amputated fingers. ${ }^{1}$ The mean number of corpuscles in the elderly sample showed a reduction to $28 \%$ of the figure obtain ed for the young material for the palmar site and to $34 \%$ and $23 \%$ respectively for the lateral and dorsal sites.

Other receptors Pacinian corpuscles were relatively frequent in both palmar and lateral skin, though not as abundant as in the young material and none were observed in dorsal skin: no counts were made. No other type of organised receptor was observed in any site examined, and few identifiable Merkel cells were seen.

\section{TACTILE THRESHOLDS}

General The nature of the responses varied as it had done in the young group previously examined. ${ }^{1}$ Some subjects were hesitant, particularly round threshold levels, and became confident as the threshold was exceeded. Some responded very slowly and deliberately, and some occasionally answered to both the "on" and the "off" phase of a single stimulus. False positive responses were rare. The comfortable, quiet surroundings, the simplicity of the apparatus and procedure, and the relatively short time involved (about 30 
Table 3 Mean threshold in grams with standard errors

\begin{tabular}{|c|c|c|c|}
\hline & \multicolumn{3}{|l|}{ Site } \\
\hline & Palmar & Lateral & Dorsal \\
\hline Males & $\begin{array}{c}0.24 \\
\pm \\
0.05\end{array}$ & $\begin{array}{c}0.40 \\
\pm \\
0.07\end{array}$ & $\begin{array}{c}0.58 \\
\pm \\
0.15\end{array}$ \\
\hline Females & $\begin{array}{c}0.15 \\
\pm \\
0.03\end{array}$ & $\begin{array}{c}0.32 \\
\pm \\
0.06\end{array}$ & $\begin{array}{c}0.43 \\
\pm \\
0.15\end{array}$ \\
\hline Combined & $\begin{array}{c}0.19^{*} \\
\pm \\
0.03\end{array}$ & $\begin{array}{c}0.36 \\
\pm \\
0.09\end{array}$ & $\begin{array}{c}0.50 \\
\pm \\
0 \cdot 13\end{array}$ \\
\hline
\end{tabular}

*Significantly lower than the values for the lateral $(p<0.001)$ or for the dorsal $(\mathrm{p}<0.001)$ sites.

Table 4 Mean threshold in grams with standard errors

\begin{tabular}{|c|c|c|c|}
\hline & \multicolumn{3}{|l|}{ Site } \\
\hline & Palmar & Lateral & Dorsal \\
\hline $\begin{array}{l}{ }^{*} \text { Combined sexes } \\
\text { young subjects }\end{array}$ & $\begin{array}{c}0.07 \\
\pm \\
0.006\end{array}$ & $\begin{array}{c}0.16 \\
\pm \\
0.03\end{array}$ & $\begin{array}{c}0.19 \\
\pm \\
0.06\end{array}$ \\
\hline $\begin{array}{l}\text { Combined sexes } \\
\text { elderly group }\end{array}$ & $\begin{array}{c}0.19 \\
\pm \\
0.03\end{array}$ & $\begin{array}{c}0.36 \\
\pm \\
0.09\end{array}$ & $\begin{array}{c}0.50 \\
\pm \\
0.13\end{array}$ \\
\hline
\end{tabular}

*From Bruce and Sinclair. ${ }^{1}$

minutes to test all three sites) ensured that attention and concentration could be maintained throughout the testing period.

Effect of skin temperature Skin temperature ranged from $22 \cdot 1{ }^{\circ} \mathrm{C}$ to $35 \cdot 1{ }^{\circ} \mathrm{C}$, but as in the young subjects previously examined, there was no correlation between the skin temperature and the tactile threshold.

Effect of sex Although the values for thresholds were smaller for the females in all three sites (table 3 ), the differences were not statistically significant $(p>0.1$ for the palmar site; $p>0.3$ lateral; $\mathrm{p}>0.2$ dorsal).

Effect of site Table 3 shows that there was no significant difference between the mean thresholds obtained from the dorsal and lateral sites $(p>0 \cdot 1)$, although the figures for the dorsal surface were higher. The palmar surface was significantly more sensitive than either of the other two sites $(\mathrm{p}<0.001)$ in both cases).

Effect of age Table 4 compares the thresholds found in the present investigation with those obtained for the young group by Bruce and Sinclair. ${ }^{1}$ The thresholds were elevated by a factor of 2.7 (compared with the mean value in the young group) on the palmar surface; by $2 \cdot 2$ on the lateral surface and by 2.6 on the dorsal surface. Within the age range of the elderly group

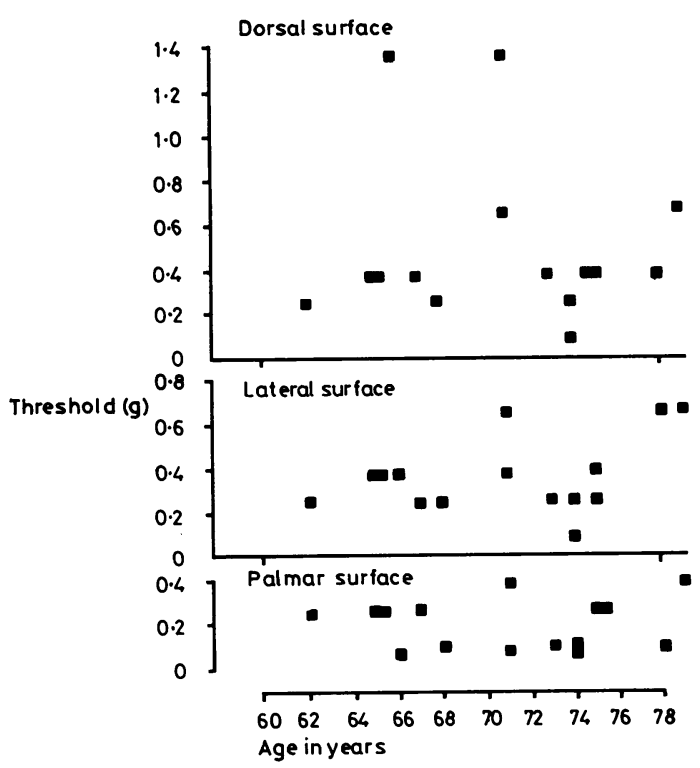

Fig 3 Effect of advanced age on tactile thresholds.

studied there was no clear evidence of a very marked decline in sensitivity as age advanced (fig 3).

\section{Discussion}

Exactly why Meissner corpuscles are reduced in number, change in shape and size, and show a tendency to drift away from the epidermis in old age is not known, but the present quantitative and morphological findings are in conformity with previous work. ${ }^{2358}$ It has been suggested by Cauna $^{3}$ that occupational wear and tear might be a factor, and in fact the decrease in number of corpuscles is slightly less on the lateral surface, which is the most sheltered of the three sites sampled.

It is possible, however, that the primary factor is to be found, not in the effect of trauma to the skin, but in the peripheral nervous system. Corbin and Gardner $^{7}$ reported a $32 \%$ decrease in the number of myelinated fibres in human peripheral nerves, and Gardner ${ }^{8}$ a similar decrease in the number of spinal ganglion cells though this was not confirmed by Ohta et al. ${ }^{9}$ Swallow $^{10}$ reported a significant decrease in the proportion of large diameter fibres with age, while Weddell ${ }^{11}$ found an increase with age in the number of fibres in the radial nerve but a decrease in their diameter. There also is conflicting evidence regarding a possible reduction in the number of unmyelinated 
fibres with age. ${ }^{12} 13$ The Meissner corpuscles, although supplied by myelinated fibres have no monopoly of them, and it is likely that any reduction in the number of nerve fibres would produce a general reduction in the number of terminals of many kinds; the changes in the Meissner population would simply be among the most easily noticed.

In the elderly subjects the elevation in touch thresholds is of the same order in all three sites, suggesting a general process affecting receptor efficiency. This could simply result from a loss of nerve fibres, or from changes in skin structure ${ }^{14-16}$ which could reduce the efficiency of stimulus transmission.

It is generally agreed that sensitivity within the modality of touch deteriorates in old age, though relevant literature is remarkably sparse. Jalavisto et $\mathrm{l}^{17}$ found a gradual decline in corneal sensitivity to touch until the age of about 50, after which it accelerated. Ronge ${ }^{2}$ associated a reduction in tactile acuity in the fingers with a reduction in the number of Meissner corpuscles, but Dickens et $a l^{5}$ noted that the age-related decrease in acuity did not correspond with the fall in the number of corpuscles. Dyck et al ${ }^{18}$ recorded a decrease in tactile acuity on the dorsum of the index finger and the great toe, and Bolton et $a i^{6}$ found a decrease in two-point discrimination, as did Gellis and Pool. ${ }^{19}$ Newman and Corbin ${ }^{20}$ reported a lessening of vibration sensitivity in the digits, and Cosh ${ }^{21}$ confirmed this for the toes, but found it did not occur to the same extent in the fingers. Bender ${ }^{22}$ found that nearly half of a group of 150 subjects over 60 years of age showed mild defects of vibration sense; this was associated with a sharp decrease after the age of 65 in the ability to detect and localise stroking stimuli on the face and the dorsum of the hand. There is some evidence that elevation of the thresholds starts earlier than the age of the youngest of the present group, ${ }^{1719}$ and the results reported here suggest that the major decline in tactile threshold must have preceded the sixties.

There was no evidence of sex differences in threshold in any of the three sites in either the young ${ }^{1}$ or the older group, and this conflicts with the findings of Weinstein ${ }^{23}$ and Dyck et al. ${ }^{18}$ This may be because both the young and the older groups studied in this laboratory were particularly well matched for handedness, background (the young group were medical students), motivation and intelligence. The elderly group in particular probably represents a section of the population which takes unusually good care of the hands, so minimising the effects of differences in skin care or exposure to minor trauma. In contrast, Weinstein's group consisted of students, skilled and unskilled workers, while Dyck et al give no details of the group which they studied.

In the previous study on young adults ${ }^{1}$ the most striking finding was the discrepancy between the touch detection thresholds and the population of Meissner corpuscles. The results reported here confirm the lack of correspondence between sensory thresholds and receptor densities. The palmar surface of the finger was significantly more sensitive than the lateral surface despite the fact that the mean number of corpuscles was slightly higher on the lateral surface while the lateral surface was not significantly different in sensitivity from the dorsal surface despite the significantly greater number of corpuscles on the former.

Thus the results of the present study reinforce the opinion of Bruce and Sinclair ${ }^{1}$ that Meissner corpuscles are not primarily responsible for the passive thresholds in human finger skin.

Before an explanation can be given for the decrease in touch thresholds in old age, more quantitative information will be needed on the age changes in skin structure and innervation and on the age changes in the peripheral and central nervous systems.

I am grateful to Professor DC Sinclair for his comments on the manuscript, to $\mathrm{Mr}$ A Michie for technical assistance and to the volunteers who took part.

\section{References}

1 Bruce MF, Sinclair DC. The relationship between tactile thresholds and histology in the human finger. J Neurol Neurosurg Psychiatry 1980; 43: $235-42$.

2 Ronge H. Alterveranderungen der Meissnerchen Korperchen in der Fingerhaut. Z Mikrosk Anat Forsch 1943; 54:167-77.

3 Cauna $\mathbf{N}$. The effects of ageing on the receptor organs of the human dermis. In: Montagna W, ed. Ageing. Advances in the Biology of the Skin vol. 6. Oxford: Pergamon 1964; 63-93.

4 Fitzgerald MJT. Double impregnation silver technique for nerve fibres in paraffin sections. Q J Microscop Sci 1964; 105:359-61.

5 Dickens WN, Winklelmann RK, Mulder DW. Cholinesterase demonstration of dermal nerve endings in patients with impaired sensation. Neurology (Minneap) 1963; 13:91-100.

6 Bolton CF, Winkelmann RK, Dyck PJ. A quantitative study of Meissner's corpuscles in man. Neurology (Minneap) 1966; 16:1-9.

7 Corbin KB, Gardner ED. Decrease in the number of myelinated fibres in human spinal roots with age. Anat Rec 1937; 68:63-74. 
8 Gardner ED. Decrease in human neurones with age. Anat Rec 1940; 77:529-36.

9 Ohta M, Offord D, Dyck PJ. Morphometric evaluation of the first sacral ganglia of man. J Neurol Sci 1974; 22:73-82.

10 Swallow M. Fibre size and content of the anterior tibial nerve of the foot. J Neurol Neurosurg Psychiatry 1966; 29:205-13.

11 Weddell G. Activity pattern hypothesis for sensation of pain. In: Grenell RG, ed. Neural Physiopathology $1963 ; 134-77$.

12 Ochoa J, Mair WG. The normal sural nerve in man II. Changes in the axons and Schwann cells due to ageing. Acta Neuropathol (Berl) 1969; 13:217-39.

13 Behse F, Buchtal F, Carlsen F, Knappies GG. Unmyelinated fibres and Schwann cells in neuropathy. Brain 1975; 98:493-510.

14 Pearce H, Grimmer BJ. Age and chemical constitution of the human dermis. J Invest Dermatol 1972; 58:347-61.

15 Kostowlicki M, Lewicka-Kus L. Variations of the subepidermal elastic plexus of the ageing human skin. Z Mikrosk Anat Forsch 1971; 84:145-98.

16 Jarrett A. Ageing of the Epidermis. In: Jarrett
A, ed. The Physiology and Pathophysiology of the Skin. vol. 1. London and New York: Academic 1973; 116-21.

17 Javalisto E, Orma E, Tawast M. Ageing and the relation between stimulus intensity and duration in corneal sensibility. Acta Physiol Scand 1951; 23:224-33.

18 Dyck PJ, Schultz RW, O'Brien PC. Quantitation of touch pressure sensation. Arch Neurol 1972; 26:465-73.

19 Gellis M, Pool R. Two point discrimination distances in the normal hand and forearm. J Plast Reconst Surg 1977; 59:57-63.

20 Newman HW, Corbin KB. Quantitative determination of vibratory sensibility. Proc Soc Exp Biol Med 1936; 35:273-6.

21 Cosh JA. Studies on the nature of vibration sense. Clin Sci 1953; 12:131-5.

22 Bender $M$. Perceptual deficiencics in the aged. In: Fields WS, ed. Neurological and Sensory Disorders in the Elderly. New York: Stratton $1975 ; 15-31$.

23 Weinstein $\mathbf{S}$. Intensive and extensive aspects of tactile sensitivity as a function of body part, sex and laterality. In: Kenshalo DR, ed. The Skin Senses. Springfield: Thomas, 1968; 195-222. 